\title{
Effect of Key Financial Drivers on Organizational Performance: Evidence from Public Establishments in Nigeria
}

\author{
Lawal Babatunde Akeem \\ Department of Accounting \& Finance \\ McPherson University Seriki-Sotayo, Ogun State, Nigeria
}

Keywords

Financial drivers, cash flow management, cost management, performance, organization and establishments.

\begin{abstract}
This paper examined the effect of key financial drivers on organizational performance of public establishments in Nigeria. There exists difficulty in achieving continued exercise and growth, poor management funding, failure to adequately anticipate cash flow, technology or reaction to competition with private establishments, indiscipline among members in public ministry and ill-timed financing. The objectives of this study are therefore to; examine the effect of cash flow management on organizational performance of public establishments in Nigeria and examine the effect of cost management on organizational performance of public establishments in Nigeria. The research design for this study was experimental design used to test the hypothesis in reaching a valid conclusion. The population of the study comprised of the public establishments in Ogun State, and the target population of the study was Agbado District Comprehensive High School, Oke Aro, Ogun State using purposive sampling. The study employed the use of primary data through the administering of questionnaire. Multiple regression models were used to analyze the data. Based on the findings, the study recommended that public establishments should take advantage of the excellent benefits derivable from the adoption of well-designed cash flow management. Also, public establishments should carefully implement cost management techniques to aid business performance and ensure continuity.
\end{abstract}

Corresponding author: Lawal Babatunde Akeem

Email address for corresponding author: ab400level@yahoo.com

First submission received: 3oth November 2018

Revised submission received: $28^{\text {th }}$ March 2019

Accepted: 30th March 2019

\subsection{Introduction}

Organizational performance concept is core to public enterprises because the objective of government companies is to achieve profit, productivity and success. Mutindi, Namusonge and Obwogi (2013) observed that one of the important questions in business have been why some organizations succeed and why others fail, and this has influenced a study on the drivers of organizational performance. Kangangi (2014) highlighted performance measurement as one of the tools, which help firms in monitoring performance, identifying the areas that need attention, enhancing motivation, improving communication and strengthening accountability.

Gichuki (2012) describes performance in terms of four perspectives, which are the financial, customer, internal processes and innovativeness. The financial perspective identified the key financial drivers of enhancing performance that are profit margin, asset turnover, leverage, cash flow, and working capital. Financial drivers of performance involve the translation of business strategies into deliverable results. It combines financial and operating principles to gauge how a company is able to meet its targets 
(Mshenga \& Owuor, 2009). Financial drivers of performance are closely linked to specific key drivers in order to maximize organizational performance.

Cash flow management as an important financial driver on performance of Public establishment. Waltson and Head (2009) explained cash management as the concept which is concerned with optimizing the amount of cash available, maximizing the interest earned by spare funds not required immediately and reducing losses caused by delays in the transmission of funds. Public establishments must have enough cash to meet its obligations or it will be declared bankrupt. Creditors, employees and lenders expect to be paid on time and cash is the required medium of exchange. Mutti and Hughes (2002) on cash flow management of public establishments in the UK revealed that insolvencies are higher in public establishments as compared to other sectors, siting the major cause of failure as lack of financial control and poor management. The study elaborates that with a good cash flow management such establishments can be kept operating and financially healthy. Failure can be prevented using models of cash flow management and forecasting that form a basis for mangers to rethink their cash flow management practices.

Cost management as an important financial driver on performance of Public establishment. Stenzel (2010) discussed that cost management means knowledge of resources used by company, forecast amount of additional financial resources necessary, and the ability to ensure the maximum efficiency level of resources used. It is also the ability to save resources and at the same time maximize their efficiency. Cost management is among the most important activity in an organization that has an impact over the business functions in a company. There are arguments that imply that cost management is another factor that is likely to level up competitive advantage. Cost management is described as the approaches and activities of executives and top-level managers in the short run and long run planning and control decisions to increase customer satisfaction as well as reduce costs of production.

A number of public establishments have continually experienced shortage in performance and finance in relation to their business and service operations, despite its importance to the success of these establishments. This could be lack of sound knowledge in utilizing financial drivers by the Board of directors or financial managers. In addition, there is difficulty in ascertaining whether comprehensive finance schemes that satisfied the laws under which it was incorporated had been kept.

The broad objective of this study is to examine the effect of key financial drivers on the performance of public establishments in Nigeria. Specific objectives are to:

- Investigate the effect of cash flow management on the performance of public establishments in Nigeria.

- Examine the effect of cost management on the performance of public establishments in Nigeria.

However, to attain the desired results, managers need statistical figures and costs of the actual performance of the establishment to compare them with the planned budget performance in order to supervise and control costs (Crossman, 1953).

\subsection{Literature Review}

2.1 Theoretical Review

\section{Baumol's Cash Management Model}

The model was designed to minimize the sum of opportunity cost associated with holding cash and trading costs associated with converting other to cash. The procedure is very similar to the EOQ Model for inventory size, but it deals with different variables. It assumes that the firm holds a portfolio of marketable securities which can easily be converted into cash (Baumol, 1952). According to this model, cash is assumed to start from a replenishment level, $\mathrm{C}$, and then declines smoothly to a value zero. When cash declines to zero, it can be immediately replenished by selling another $\mathrm{C}$ worth of marketable 
securities, for which the firm has to pay a trading cost of F (Cornett 2009). In Baumol model, the financial manager has to decide on the repartition of liquid funds between cash and marketable securities (Pandey, 2008).

\section{Transaction Cost Theory}

Transaction cost theory is used to explain a number of different behaviors. Often this involves considering as transactions not only the obvious cases of buying and selling but also day to day emotional interactions and informal gift exchanges (Williamson, 1975). The transaction cost theory suggests that there are certain costs that people normally incur without knowing that they are a cost to them. These costs must be incurred whenever a transaction takes place. These costs are known as transaction costs. John R. Common introduced the idea that transactions form the basis of an economic thinking in 1931 (Williamson, 1975).

Transaction cost theory focuses on transactions and costs that attend completing transactions by one institutional mode rather than another (Williamson, 1975). The theory's central claim is that the transactions will be handled in such a way as to minimize the costs involved in carrying them out (Muchina \& Kiano, 2011). A transaction, a transfer of good or service is the unit of analysis in transaction cost theory and the means of effecting the transaction is the principal outcome of interest (Williamson, 1975).

\subsection{Conceptual Review}

A conceptual framework is a set of broad ideas and principles taken from relevant fields of enquiry and used to structure a subsequent presentation (Kombo \& Tromp, 2006). The conceptualization of variables in academic study is important because it forms the basis for testing hypothesis and coming up with generalizations in the findings of the study (Wael, 2017). In this study, the independent variables are the conceptualized key financial drivers of public establishments' performance. The independent variables of the study include cash flow management and cost management.

The dependent variable is performance. The independent variables thus affect the dependent variable, which is organizational performance. The study, therefore, seeks to determine how the independent variables influence the dependent variable in public establishments in Ogun state.

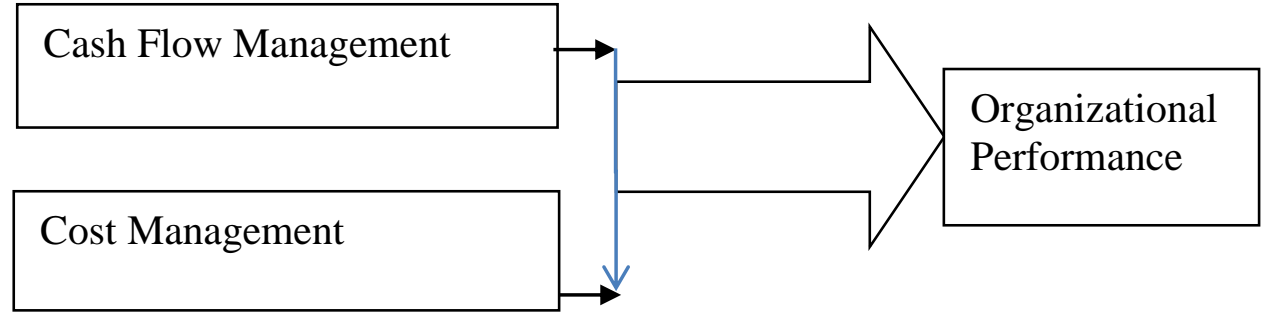

Independent Variables

Dependent Variable

\section{Fig. 2.1 Conceptual Model}

\section{Cash Flow Management}

Cash flow management is the process of planning and controlling cash flows into and out of business, cash flows within the business, and cash balances held by a business at a point in time (Pandey, 2008). Naser, Nuseibel and Al-Hadeya (2013) see cash management as the process of ensuring that enough cash is available to meet the running expenses of a business and aims at reducing the cost of holding cash. Efficient cash management involves the determination of the optimal cash to hold by considering the 
trade-off between the opportunity cost of holding too much cash and the trading cost of holding too little cash (Ross 2008). Atrill (2006) asserts that there is a need for careful planning and monitoring of cash flows over time to determine the optimal cash to hold.

Mihaiu (2014) opined that cash-flow management is vital to the health of public establishments. Each time through the cycle, a little more money is put back into public establishments than flows out. When cash flow is not monitored and corrective action not taken, public establishments may find itself sinking into trouble. Cash outflows and inflows seldom seem to occur together. More often than not, cash inflows seem to lag behind cash outflows, leaving public establishments short.

\section{Cost Management}

Hansen (2005) explained that all organizations identify cost management as a goal and a practice. Managing cost however differs greatly from accounting in public establishments, and while many organizations feel that they are managing costs, they are in fact they are only accounting for them. Such organizations are depriving themselves of the benefits that management processes deliver. Simply stated, cost accounting addresses "how much" and "what for." It is not analytical and merely addresses history or tells us what happened.

\section{Empirical Review}

Anyanwu (1999) succinctly explained that despite the great expectations that spurred the establishment of Public Enterprises and the huge investments and subventions pumped to float and maintain them, they have remained a colossal drain on the nation's hard-earned resources with little positive impact on the socio-economic life of the country. The Fourth National Development Plan (19751980) states that: "The actual performance of the Public Enterprises in Nigeria leaves much to be desired. It is clear that many of them are not responding to the changing and dynamic economy. Some do not possess the tools for translating into reality, the hope of successful commercial operations. The level and quality of personnel are sometimes mediocre and reflect the worst traditions and rigidities of the civil services".

In the study of Ademolekan and Gboyega, (1979), profit is the commonest measure of efficiency in productive organizations, but it is usually regarded as non-profit; and as is to be expected, an evaluation of their performance is usually required. A resolution of this dilemma has been a major concern among scholars; the solution, however, has remained elusive. This exercise is significant, given the increasing use to which Public Enterprise as an organizational form is justifiably being put in many developing politics. In Nigeria, the failure or inability of most of the Public Enterprises to achieve the objectives for which they were created is no longer in doubt. In an address to the working party appointed in 1966 in Nigeria Statutory Cooperation and state-owned companies, the then Head of State said: "The present states of the statutory corporations, state-owned companies and allied organizations have given the Federal Military Government some cause of anxiety. Sufficient time has elapsed to enable an objective fragment to be passed on whether or not these various organizations have creditably satisfied their objectives.

According to Ademolekan and Gboyega, (1979), in an effort to reverse the above ugly tide, Nigerian government in the early 1980s made effort to use performance contract to measure the performance of Public Enterprises in Nigeria. This plan constitutes a pact between a government and the management of the Public Enterprise by stating the objectives to be achieved within a given specific terms and conditions for attaining the objectives. Normally the agreement includes a formal commitment of the government to provide the necessary resources for the enterprise. The outcome of this exercise produced poor results. 
A notable example is a 1979 two-year management service agreement with Rail India Technical Services and the Dutch Royal Airtime to assist in improving the performance of the Nigerian Railways Corporation and the Nigerian Airways, respectively. The pacts were signed in 1979, but the temporary improvement in service could not be sustained. Obviously, attaining improved performance in Public Enterprises requires more far-reaching reform in and greater commitment on the part of the government and her leadership and the management of the Public Enterprises (Ademolekan \& Gboyega, 1979).

\subsection{Methodology}

The research design used in this study was experimented design. An experimental design is such that the researcher undertakes the research using a predetermined plan of the research process that enables the researcher to test this hypothesis thereby reaching valid conclusions about the relationships between the variables being tested. The population of the study consists of all the public establishments in Ogun state as at year 2016. The target population of the study is focused on Agbado District Comprehensive High school, Ifo, Ogun State. The sampling technique adopted for this study is a nonprobabilistic method of sampling known as purposive sampling. Primary method of data collection was employed in this study. The primary data obtained was essentially through the administration of welldesigned questionnaire to staff of the school. The sampling frame consists of the executive, administrative and teaching staff of the school that has prior understanding of what financial drivers entails. Therefore, the sampling frame consists of sixty staff within Agbado District Comprehensive High school. The study employed quantitative method of data using the multiple regression analysis. The model used an independent variable (key financial drivers) and a dependent variable (organizational performance), which are measured by cash flow management and cost management.

Model Specification

The model specified for this study is stated as follows:

$Y=f(X)$

Where $\mathrm{Y}=$ Organizational Performance (dependent variable)

$\mathrm{f}=$ functional relationship

$\mathrm{X}=$ Key Financial Drivers (independent variable)

Multiple Regression Model

$Y=\beta_{0+} \beta_{1} x_{1}+\beta_{2} x_{2}+e i$

$\mathrm{OP}=\beta_{0+} \beta_{1} \mathrm{CFM}+\beta_{2} \mathrm{CM}+\mathrm{ei}$

Where;

$\mathrm{OP}=$ Organizational Performance

$\beta_{0}=$ constant

$\beta_{1}, \beta_{2}=$ Model Coefficient

ei $=$ Error term

$\mathrm{x}_{1}=$ Cash Flow Management (CFM)

$\mathrm{x}_{2}=$ Cost Management $(\mathrm{CM})$

\subsection{Data Presentation, Analysis and Discussion}

This section presents the properties of the data used for this study in order to understand the variables as well as the suitability for this study. It will assist in drawing inference under the test of hypothesis. 


\subsection{Demographic Data}

This section considers the peculiarity of each respondent in terms of age, sex, marital status. The frequency and percentage are given below.

Table 4.1: Sex

\begin{tabular}{|ll|l|l|l|l|}
\hline & & Frequency & Percent & Valid Percent & Cumulative Percent \\
\hline \multirow{3}{*}{ Valid } & Male & 26 & 43.3 & 43.3 & 43.3 \\
& Female & 34 & 56.7 & 56.7 & 100.0 \\
& Total & 60 & 100.0 & 100.0 & \\
\hline
\end{tabular}

Source: Author's Computation (2018)

The table above shows the distribution of gender of the respondents. It was revealed that $56.7 \%$ of the respondents are female while 43.3 are male respondents.

Table 4.2: Marital Status

\begin{tabular}{|ll|l|l|l|l|}
\hline & & Frequency & Percent & Valid Percent & Cumulative Percent \\
\hline \multirow{4}{*}{ Valid } & Single & 25 & 41.7 & 41.7 & 41.7 \\
& Married & 25 & 41.7 & 41.7 & 83.3 \\
& divorced & 10 & 16.7 & 16.7 & 100.0 \\
& Total & 60 & 100.0 & 100.0 & \\
\hline
\end{tabular}

Source: Author's Computation (2018)

Table 4.2 shows that the percentage of married and single respondents as the same $(41.7 \%)$ while $16.7 \%$ are divorced.

Table 4.3: Age

\begin{tabular}{|ll|l|l|l|l|}
\hline & & Frequency & Percent & Valid Percent & Cumulative Percent \\
\hline \multirow{5}{*}{ Valid } & Less than 20years & 4 & 6.7 & 6.7 & 6.7 \\
& $20-29$ years & 21 & 35.0 & 35.0 & 41.7 \\
& $30-39$ years & 23 & 38.3 & 38.3 & 80.0 \\
& $40-49$ years & 12 & 20.0 & 20.0 & 100.0 \\
& Total & 60 & 100.0 & 100.0 & \\
\hline
\end{tabular}

Source: Author's Computation (2018)

The age pattern of the respondents is given above. It shows that $38 \%$ are between $30-39$ years while $35 \%$ falls between $20-29$ years. Only about $6.7 \%$ are less than 20 years while $320 \%$ are between $40-49$ years.

Table 4.4: Years of Experience

\begin{tabular}{|ll|l|l|l|l|}
\hline & Frequency & Percent & Valid Percent & Cumulative Percent \\
\hline \multirow{4}{*}{ Less than 1 year } & 9 & 15.0 & 15.0 & 15.0 \\
& 1 - 5 years & 10 & 16.7 & 16.7 & 31.7 \\
Valid -10 years & 14 & 23.3 & 23.3 & 55.0 \\
& 10 years and above & 27 & 45 & 45.0 & 100 \\
& Total & 60 & 100.0 & 100.0 & \\
\hline
\end{tabular}

Source: Author's Computation (2018)

It is observed from the table above that $45 \%$ of the respondents have worked for 10years and above, $16 \%$ have of working experience of $1-5$ years while $15 \%$ worked for less than 5 years. 
Table 4.5: Educational Qualification

\begin{tabular}{|ll|l|l|l|l|}
\hline & Frequency & Percent & Valid Percent & Cumulative Percent \\
\hline \multirow{4}{*}{ Valid } & OND/NCE & 14 & 23.3 & 23.3 & 23.3 \\
& B.Sc./BA/HND & 19 & 31.7 & 31.7 & 55.0 \\
& MBA/MSc & 25 & 41.7 & 41.7 & 96.7 \\
& Others & 2 & 3.3 & 3.3 & 100.0 \\
& Total & 60 & 100.0 & 100.0 & \\
\hline
\end{tabular}

Source: Author's Computation (2018)

The educational qualifications of the respondents are shown above. 23.3\% have OND/NCE, 31.7\% have obtained first degree while $41.7 \%$ have second degree. About $3.3 \%$ of the respondents have other qualifications not listed above.

Table 4.6: Classification of Staff

\begin{tabular}{|ll|l|l|l|l|}
\hline & Frequency & Percent & Valid Percent & Cumulative Percent \\
\hline \multirow{4}{*}{ Valid } & Executive staff & 3 & 5.0 & 5.0 & 21.7 \\
& Administrative staff & 23 & 38.3 & 38.3 & 60.0 \\
& Teaching Staff & 34 & 56.7 & 56.7 & 100.0 \\
& Total & 60 & 100.0 & 100.0 & \\
\hline
\end{tabular}

Source: Author's Computation (2018)

It is observed from the tale above that most of the respondents are teachers as they have a percentage of $56.7 \%, 38 \%$ are administrative staff while only $3 \%$ are executive staff.

Questions Relating to Key financial Drivers and Organizational Performance Table 4.7: Cash Flow Management

\begin{tabular}{|l|l|l|l|l|l|l|}
\hline & $\mathrm{SA}(\%)$ & $\mathrm{A}(\%)$ & $\mathrm{U}(\%)$ & $\mathrm{D}(\%)$ & $\mathrm{SD}(\%)$ & Total (\%) \\
\hline $\begin{array}{l}\text { Cash Flow management provides } \\
\text { information to enable the control of cash in } \\
\text { public establishments. }\end{array}$ & $22(36.7 \%)$ & $14(23.3 \%)$ & $10(16.7 \%)$ & $14(23.3 \%)$ & - & $60(100 \%)$ \\
\hline $\begin{array}{l}\text { Cash flow management is essential for } \\
\text { financial decision making in public } \\
\text { establishment. }\end{array}$ & $24(40 \%)$ & $13(21.7 \%)$ & $7(11.7 \%$ & $25(25 \%)$ & $1(1.7 \%)$ & $60(100 \%)$ \\
\hline $\begin{array}{l}\text { Cash flow management support public } \\
\text { establishment audit and research. }\end{array}$ & $19(31.7 \%)$ & $14(23.3 \%)$ & $4) 6.7 \%)$ & $18(30 \%)$ & $5(8.3 \%)$ & $60(100 \%)$ \\
\hline $\begin{array}{l}\text { Cash flow management is essential for } \\
\text { preparation of financial statement. }\end{array}$ & $17(28.3 \%)$ & $21(35 \%)$ & $6(10 \% 0$ & $12(20 \%)$ & $4(6.7 \%)$ & $60(100 \%)$ \\
\hline $\begin{array}{l}\text { Cash flow management assist in detecting } \\
\text { theft within the establishment. }\end{array}$ & $21(35 \%)$ & $16(26.7 \%)$ & $6(10 \%)$ & $12(20 \%)$ & $5(8.3 \%)$ & $60(100 \%)$ \\
\hline
\end{tabular}

Source: Author's Computation (2018)

It is observed that $60 \%$ cumulatively agreed that cash Flow management provides information to enable the control of cash in public establishments, $40 \%$ agreed that Cash flow management is essential for financial decision making in public establishment while 25\% disagreed. Also, $30 \%$ disagreed that Cash flow management support public establishment audit and research, 32\% strongly agreed while 35\% 
agreed that Cash flow management is essential for preparation of financial statement, $20 \%$ disagreed that Cash flow management assist in detecting theft within the establishment. It therefore suggests that cash flow management is essential and needed by firms.

Table 4.8

Cost Management

\begin{tabular}{|l|l|l|l|l|l|l|}
\hline & $\mathrm{SA}$ & $\mathrm{A}$ & $\mathrm{U}$ & $\mathrm{D}$ & $\mathrm{SD}$ & Total (\%) \\
\hline $\begin{array}{l}\text { Cost management helps reduce operating } \\
\text { costs, improves efficiency and } \\
\text { productivity. }\end{array}$ & $40(66.7 \%)$ & $12(20 \%)$ & $4(6.7 \%)$ & $4(6.7 \%)$ & - & $60(100 \%)$ \\
\hline $\begin{array}{l}\text { Cost management helps public } \\
\text { establishment to attain effective costing } \\
\text { system. }\end{array}$ & $34(56.7 \%)$ & $11(18.3 \%)$ & $5(8.3 \%)$ & $8(13.3 \%)$ & $2(3.33 \%)$ & $60(100 \%)$ \\
\hline $\begin{array}{l}\text { There is an effect of cost management on } \\
\text { efficient expenditure in public } \\
\text { establishment. }\end{array}$ & $38(63 \%)$ & $9(15 \%)$ & $4(6 \%)$ & $7(11 \%)$ & $2(3 \%)$ & $60(100 \%)$ \\
\hline $\begin{array}{l}\text { Cost management assist in better } \\
\text { management of the public establishment } \\
\text { resources. }\end{array}$ & $25(41.7 \%)$ & $17(28.3 \%)$ & $5(8.3 \%)$ & $11(18.3 \%)$ & $2(3.3 \%)$ & $60(100 \%)$ \\
\hline $\begin{array}{l}\text { Cost management assists the pricing } \\
\text { system in public establishment. }\end{array}$ & $21(35 \%)$ & $16(26.7 \%)$ & $5(8.3 \%)$ & $17(28.3 \%$ & $1(1.7 \%)$ & $60(100 \%)$ \\
\hline
\end{tabular}

Source: Author's Computation (2018)

Table 4.8 analyze the questions related to cost management, it was discovered that $66.7 \%, 20 \%, 6.7 \%$ strongly agreed, agreed, disagreed that Cost management helps reduce operating costs, improves efficiency and productivity respectively. It was also observed that $56.7 \%$ agreed that cost management helps public establishment to attain effective costing system, $13.3 \%$ disagreed to this. Respondents also believe that cost management has effect on efficient expenditure in public establishment as about $78 \%$ cumulatively agreed to this. Also, $41.7 \%$ strongly agreed that Cost management assist in better management of the public establishment resources while $18.3 \%$ disagreed to this. It was also revealed that $35 \%$ strongly agreed that cost management assists the pricing system in public establishment, $26.7 \%$ agreed, $28.3 \%$ disagreed while $1.7 \%$ strongly disagreed to this.

Table 4.9: Organizational Performance

\begin{tabular}{|l|l|l|l|l|l|l|}
\hline & SA & A & U & D & SD & Total (\%) \\
\hline $\begin{array}{l}\text { This establishment applies key financial } \\
\text { drivers in operation. }\end{array}$ & $36(60 \%)$ & $15(25 \%)$ & $3(45 \%)$ & $4(6.7 \%)$ & $2(3.3 \%)$ & $60(100 \%)$ \\
\hline $\begin{array}{l}\text { It is necessary to apply financial drivers in } \\
\text { public establishment. }\end{array}$ & $37(61.7 \%)$ & $14(23.3 \%)$ & $5(8.3 \%)$ & $4(6.7 \%)$ & - & $60(100 \%)$ \\
\hline $\begin{array}{l}\text { Key financial drivers aid efficiency in public } \\
\text { establishment. }\end{array}$ & $31(53 \%)$ & $16(27 \%)$ & $4(6 \%)$ & $8(13 \%)$ & $1(1 \%)$ & $60(100 \%)$ \\
\hline $\begin{array}{l}\text { Organizational performance positively } \\
\text { depends on financial drivers. }\end{array}$ & $21(35 \%)$ & $17(28 \%)$ & $4(7 \%)$ & $16(26 \%)$ & $2(3 \%)$ & $60(100 \%)$ \\
\hline $\begin{array}{l}\text { Key financial drivers aid organizational } \\
\text { productivity and success. }\end{array}$ & $43(71.7 \%)$ & $12(20 \%)$ & $2(3.3 \%)$ & $3(5 \%)$ & - & $60(100 \%)$ \\
\hline
\end{tabular}

Source: Author's Computation (2018) 
In terms of organizational performance, $60 \%$ strongly agreed that establishment applies key financial drivers in operation, $45 \%$ were undecided while $6.7 \%$ disagreed. Sixty seven percent $(61.7 \%)$ strongly agreed that it is necessary to apply financial drivers in public establishment while $6.7 \%$ disagreed. Again, 53\% strongly agreed that key financial drivers' aid efficiency in public establishment, $27 \%$ agreed while $13 \%$ disagreed. It was also revealed in Table 4.10 that organizational performance positively depends on financial drivers as $35 \%$ and $28 \%$ strongly agreed and agreed to this fact respectively, $28 \%$ disagreed to it. In addition, about $71.7 \%$ strongly agreed that key financial drivers aid organizational productivity and success, $20 \%$ agreed while $5 \%$ disagreed to this fact.

\section{Test for Multicollinearity}

Multicollinearity test was carried out to detect if there is an unacceptably high level of intercorrelation among the independent variables. The multiple regression variance inflation factor (VIF) was used as an indicator of multicollinearity. Regarding the VIF, the norm is to accept lower levels of VIF since higher levels of VIF can adversely affect the results associated with multiple regression analysis. VIF is a simple diagnostic of colinearity for each regression coefficient. Additionally, Garson (2012) asserts that based on the rule of thumb, a multicollinearity VIF $>4.0$ is adverse while other scholars have used a more tolerant cut off of VIF $>5.0$ when multicollinearity is considered adverse. This study adopted a VIF value of 4.0 as the threshold. The cash flow management had a VIF of 3.124, the cost management at 3.236. Moreover, results indicate that the VIF values of the independent variables were within the threshold of 4.0. The result shows no threat of multicollinearity for this study.

Table 4.10: Multicollinearity Test

\begin{tabular}{|l|l|l|}
\hline Variable & Tolerance & VIF \\
\hline Cash Flow Management & 0.300 & 3.124 \\
\hline Cost Management & 0.271 & 3.236 \\
\hline
\end{tabular}

Source: Authors' analysis of the multicollinearity test.

\subsection{Hypotheses Testing}

To test the hypothesis formulated, a multiple regression model is used to analyze the data gathered and the result is shown in table 4.11 below.

Table 4.11: Effect of Key Financial Drivers on Organizational Performance of Public Establishments Dependent variable OP

Method: Least Square

Sample: 60

Variable

C

Coefficient

CFM

$\mathrm{CM}$

R-squared

Adjusted R-squared

S.E. of regression

Sum squared resid

Log likelihood

F-statistic

Prob(F-statistic)

0.716327

0.169744

0.773322

0.774817

0.235612

2.720139

4.061446

41.79135

0.000000

$\begin{array}{lll}\text { Std. Error } & \text { t-Statistics } & \text { Prob. } \\ 0.303213 & 19.33445 & 0.0000 \\ 0.117444 & -6.099281 & 0.0000 \\ 0.073833 & 2.299005 & 0.0258 \\ \text { Mean dependent var } & 2.533333 \\ \text { Mean dependent var } & 0.475831 \\ \text { Akaike info criterion } & 0.034761 \\ \text { Schwarz criterion } & 0.218926 \\ \text { Hannan-Quinn criter. } & 0.105787 \\ \text { Durbin-Watson stat } & 1.632206\end{array}$

Durbin-Watson stat 


\subsection{Discussion of Findings}

The above analysis is conducted to assess the effect of key financial drivers on organizational performance of public establishments (Table 4.11). The model constant terms give positive value of 5.86 as the value for the intercept of the model. This implies that holding all other variables constant, organizational performance will increase by $58.6 \%$.

The coefficient of cash flow management (CFM) is 0 . 716.This implies that a strong positive relationship exists between cash flow management and organizational performance in the study carried out and the coefficient is also found to be statistically significant as evidenced by an examination of the prob. value (0.0000). Also, cost management $(\mathrm{CM})$ coefficient $(0.169)$ shows that a positive relationship between cost management and organizational performance while the prob. value of 0.0258 indicates that the variable is statistically significant at $5 \%$ level of significance.

The R-Squared of the model is 0.773 showing that the explanatory variables explain $77.3 \%$ of changes in the dependent variable. It remained strong even after adjusting for the degrees of freedom to $77.4 \%$ (Adjusted R-Squared). This means that in this study, the variables chosen are strong in explaining the level of organizational performance. The F-statistic, which measures the joint statistical influence of the explanatory variables in explaining the dependent variable, was found to be statistically significant at 0.05 percent level. The F-statistic figure of 41.7913 shows that the key financial drivers adopted in this study are determinants of organizational performance in Ogun state. Thus, this result can be described as good and reliable as the model was properly treated to avoid spurious results. The R-squared is strong even when adjusted for degrees of freedom. The result is thus reliable for policy formulation and forecasting purposes.

\subsection{Conclusion and Recommendation}

Effect of Cash flow management on organizational performance. The coefficient of Cash Flow Management (CFM) is 0.716 . This implies that a strong positive relationship exists between cash flow management and organizational performance in the study carried out and the coefficient is also found to be statistically significant as evidenced by an examination of the prob. value (0.0000). This resulted from the fact that cash is a key resource for organization achieving success. Managers are advised to be more careful when dealing in cash because it was established that CFM is key in influencing organizational performance. Pubic establishments should take advantage of the excellent benefits derivable from the adoption of well-designed cash flow management. This will help them to achieve a high and acceptable standard of quality in the carrying out of their operations.

Effect of Cost management on organizational performance. Cost Management (CM) coefficient (0.169) shows that a positive relationship between cost management and organizational performance while, the prob. value of 0.0258 indicates that the variable is statistically significant at $5 \%$ level of significance. It was therefore recommended that public establishments needed to identify the best procedures that would enable them to justify cost. Also, public establishments should carefully implement cost management techniques to aid business performance and ensure continuity.

\subsection{Limitations and Suggestion for Further Studies}

The researcher faced challenge of the time taken to return the questionnaire because most of the respondents did not fill them within the expected time. This was achieved by following the respondents physically through several visits and the through the use of telephone calls. Also, some respondents did not understand the academic research and they had reservations about the questionnaire as they felt their privacy was been interfered with. This was sorted by taking time to explain to them and assuring them that the results would be used for academic research purpose. 
The aim of public establishments is to satisfy the social needs of people living where it is located. To further support the management and growth of public establishments, this research study suggests that in future research studies, secondary data should be included. Also, further studies should make use of other geographical locations when determining the population area so as to get the variation of research findings from other locations.

\section{References}

Ademolekan, L., \& Gboyega, A. (1979). Leading issues in Nigeria Public Service. University of Ife Press.

Anyanwu. J., C. (1999). Analysis of Nigeria privatization, 1988-1995.

Atrill, P. (2006). Financial Management for Decision Makers. New York: Prentice Hall.

Baumol, W. (1952). "The transactions demand for cash: An Inventory Theoretic Approach. Quarterly Journal of Economics, 66 (1), 545-556.

Crossman, E., R. (1953). Co-efficient Alpha and Internal Structure of Tests.

Garson, G. 2012. Testing statistical assumptions. Asheboro, NC: Statistical Associates Publishing.

Gichuki, W., C. (2012). Effect of Cost Management Strategies on the Financial Performance of Manufacturing Companies listed on the Nairobi Securities Exchange. A research project submitted for the award of degree of Master of Science in finance, University of Nairobi, Kenya.

Head \& Watson (2009). Exploring Corporate Strategy: Text and cases, 8th edition, London, prentice Hall, Pearson education Ltd. Jones, D., Mark, B. \& Sim, J. (2007). A new look at the Antecedents.

Hansen, D., R. (2005). Cost Management: Accounting and Control $5^{\text {th }}$ edition, published in South- Western College.

Kangangi, G., W. (2014). The Role of performance management on strategy implementation in the Insurance Industry in Kenya, Strategic Journal of Business and Change Management, 2(8), 133-157.

Kombo, D., K., \& Tromp, L., A. (2006). Proposal and Thesis Writing: An Introduction, Nairobi: Paulines Publications Africa.

Mihaiu, D. (2014). Sustainable Performance of Public Organizations: Shaping a Coherent System for Implementing and Measuring the Concept. Studies in Business and Economics, 9(3).

Mutindi, J., M., Namusonge, G., S., \& Obwogi, J. (2013). Effect of Strategic Management Drivers on Organizational Performance: A Survey of the Hotel Industry in Kenya Coast. International Journal of Art and Commerce, 2(11), pp. 21-35.

Muchina, S., \& Kiano, E. (2011). Influence of Working Capital Management on Firms Profitability: A Case of SMEs in Kenya. International Business Management, 5(5), pp. 279-286.

Mutti, C., \& Hughes, W. (2002). Cash Flow Management in Construction Firms. In: Greenwood, D(Ed.), 18th Annual ARCOM Conference, 2-4 September 2002, University of Northumbria, Association of Researchers in Construction Management, vol. 1, 23-32.

Mshenga, P.., \& Owuor, G. (2009). Research Methods: Quantitative and Qualitative Approaches.

Naser, K., Nuseibel, R. \& Al-Hadeya, A. (2013). Working Capital Management and Financial Performance on manufacturing sector in Sri Lanka. European Journal of Business Management, 4(15), 23-30.

Pandey, I. M. (2008). “Financial Management", 10th Edition. New Delhi: Vikas Publishing House Pvt. Limited.

Stenzel, P. (2010). "Corporate Performance of public enterprises in Scotland. International Research Journal of Finance and Economics, 8 (5), 23-27.

Wael, O., A. (2017). New Emerging Trends in Organizational Learning to Business Enterprises Development with Special Focus on Egypt. Global Journal of Political Science and Administration, 5(5), 1-16.

Williamson, O., E. (1975). Markets and Hierarchies. Free Press, New York, USA. 